\title{
The Impact of China on the Donor Landscape in African Fragile States
}

\author{
Richard Schiere*
}

Abstract This article analyses the impact of China on the donor landscape in African fragile states. This is undertaken by first discussing the global trends of South-South collaboration as part of the broader postBusan development debate, and secondly, the specific role of China in four African fragile states, which are respectively Liberia, Angola, Mali and Sudan. The article has two main findings. Firstly, China provides additional development opportunities but is not applying the same development cooperation model as traditional Development Assistance Committee (DAC) donors. This fragmentation of global development cooperation modalities requires capacity to coordinate donors by aid-recipient countries. Secondly, as China's economic interests grow in Africa, it is also expanding its support for regional stability by participating in UN peacekeeping operations. One of the key conditions for China's participation, however, is a clear mandate by an African regional organisation such as the African Union and Regional Economic Communities. This approach ensures that China maintains its principles of respecting national sovereignty and non-interference in the domestic affairs of other countries.

\section{捐赠格局: 中国对非洲脆弱国家的影响}

理查德・斯基尔勒

本文分析了在捐赠格局层面, 中国对非洲脆弱国家的影响。首先，讨论了釜山发展 辩论后南南合作的趋势; 随后, 阐述了中国对利比里亚、安哥拉、马里和苏丹这四 个非洲脆弱国家的影响。结论主要包括两个方面。第一, 中国提供了发展机会, 但 其发展合作模式与传统的发展援助委员会捐助国并不相同。国际发展合作模式的多 样化, 要求接受援助的国家有能力在捐助国之间进行协调。第二, 随着中国在非洲 的经济利益不断增长, 中国也通过参加联合国维和行动来加强对地区稳定的支持。 中国能够参与的一个关键因素是, 非洲联盟和地区经济共同体等非洲地区组织提出 明确要求。这样能确保中国遵守其尊重国家主权和不干涉其他国家内政的原则。 


\section{Introduction}

China is one of the main drivers of economic growth and South-South cooperation in Africa.

This has contributed to the branding of Africa as an 'emerging continent', with an average growth rate of 6.6 per cent in 2012 and with five of the ten fastest growth economies of the world located on the continent (African Economic Outlook 2012, 2013). However, the growth potential of Africa is held back by 17 fragile states in Africa. ${ }^{1}$ China's engagement in fragile states is characterised by having a higher 'risk appetite' compared to investors from traditional donor countries, a respect for national sovereignty and flexibility in adapting to the domestic political environment of a country. More recently, as China's economic interests grow on the continent, it is also expanding its support for regional stability by participating in UN peacekeeping operations, although this does require a clear mandate from an African regional organisation. This approach has ensured that China maintains its principles of respecting national sovereignty and non-interference in the domestic affairs of other countries. China's engagement is therefore different from traditional DAC donors that emphasise good governance and accountability values.

This article discusses the impact of China on the donor landscape in African fragile states by first focusing on global South-South cooperation trends in the post-Busan development debate and then on the role of China in four fragile states, which are respectively, Liberia, Angola, Mali and Sudan. These four case studies provide the opportunity to gain insights into African fragile states that are faced with different institutional challenges, domestic political systems, donor relations, resource endowment and peacekeeping operations. These four countries present the diversity of African fragile states and the impact of different development cooperation modalities of China and traditional donors.

The study contributes to the academic and policy discussions by combining the literature on China-Africa and on post-conflict recovery. In the past, academic literature on the impact of China on Africa were often analyses based on aggregated trade and investment flows or based on applying a political analysis on the impact of development assistance models. More recently, the literature on the impact of China on Africa has been considered as part of wider South-South cooperation, although there are also specific sectoral impact studies (Alden 2013; Scoones, Cabral and Tugendhat 2013; Chichava et al. 2013; Mukwereza 2013; Buckley 2013; Cabral et al. 2013; Pierri 2013). A clear gap in the literature is the specific focus on the impact of China on African fragile states and this is the main focus of this article.

The article is structured as follows. The second section highlights the impact of South-South cooperation on global discussions on development aid and effectiveness. The third section emphasises some of the key economic challenges for fragile states and how China's engagement can be complementary to existing development models. The fourth section provides insights into four post-conflict-affected countries, namely Liberia, Angola, Mali and Sudan. These countries represent the diversity of African conflict-

sensitive countries. The fifth section presents the various impacts and trends of China's engagement in African fragile states. Finally, the last section discusses policy options for African fragile states and all development partners which would support the successful transition from fragility to sustainable development.

\section{Fragmentation of development cooperation models and post-Busan development debate}

Since the independence of many African countries, development cooperation relationships have been dominated by traditional donors, often referred to as DAC countries, established Multilateral Development Banks and International Institutions (e.g. the African Development Bank, Asian Development Bank, World Bank, International Monetary Fund (IMF) and United Nations (UN) agencies). These traditional donors base their interventions on 50 years of development experience and emphasise country ownership, development effectiveness, aid coordination, use of countryowned systems, the untying of aid and reducing the number of project implementation units. These issues have been enshrined in the 2005 Paris Declaration, which defines aid effectiveness principles and were crystallised into 12 indicators that track implementation. The 2008 Accra Agenda for Action reaffirmed the commitment to the Paris Declaration and also called for greater partnership between different providers of assistance on aid and development. 
Since the Paris Declaration and Accra Agenda for Action, Africa-China relations have continued to grow exponentially and are changing the donor landscape in Africa (Schiere 2010). Some observers - most notably Deborah Bräutigam are referring to the 'Beijing consensus' in which private sector development and economic growth take centre stage and investors do not interfere with domestic governance structures of African countries (Bräutigam 2010). For African countries endowed with natural resources, the growth of China's engagement has indeed provided more domestic policy freedom, compared to the previous 'Washington Consensus', which emphasised good governance and a tight macroeconomic framework. At the same time, this has led to some concerns of freeriding by traditional donors as they, for example, grant debt relief, while at the same time China offers new loans on non-concessional terms (Woods 2008; Kragelund 2008).

China does not apply the DAC-defined development cooperation model, nor does it centrally track disbursements. This means that loans, lines of credit, capacity-building initiatives and humanitarian aid are often not registered, although lately there have been some attempts by the China open aid platform. Estimates of development assistance provided by China vary between US $\$ 1$ billion to US $\$ 2$ billion (Bräutigam 2009). What is evident is that long-term assistance will gradually shift from traditional donors to emerging development partners. While emerging development partners will likely continue to have high economic growth figures, traditional donors are faced with structural public expenditure challenges linked to the debt crisis and ageing of the population. Moreover, there seems to be a decrease in political willingness by traditional donors to provide official development assistance (ODA). This is caused by the fact that the current electorate feels less engaged with Africa after more than half a century of independence. These trends will lead to the further fragmentation of aid modalities and instruments at a global level (Zimmermann and Kimberly 2011).

At national level, there are clear complementarities between the development modalities of traditional donors and China, although this would require strong and effective leadership from aid-recipient countries. A good example of how different aid modalities can be effective is the building of an Economic Process Zone, which could be supported by infrastructure development financed by China while overall competitiveness is enhanced by policy reforms through a budget support operation by traditional development partners (Schiere 2010). These kinds of complementarities are also reflected in the triangular development cooperation models, which aim at fostering cooperation between traditional donors, emerging development partners and recipient countries (Langendorf and Mueller 2011). From an African recipient perspective, the triangular development cooperation is interesting as it provides an opportunity to share best practices and learn lessons from other developing countries (Ashoff 2010), as well as increase policy and funding options.

The impact of the growing strength of South-South cooperation was evident in the Fourth High Level Forum on Aid Effectiveness in Busan (Busan Agreement 2011). This was the first time that traditional and non-traditional donors engaged in discussion on aid effectiveness principles, although application of these principles is voluntary. Emerging development partners emphasised that there should be differential commitments as they have developmental challenges of their own such as inequality and urban slums. However, it is the voluntary nature and differential commitments which led to the lack of political willingness in the implementation of the Busan agreement. This is reflected in the low participation of countries in the Global Monitoring Framework survey, which tracks the implementation of the Busan agreement. Of the 160 countries that signed the Busan agreement in 2011, less than 60 countries are participating in the survey.

There is some discomfort among traditional development partners as they are still implementing the aid effectiveness principles, while emerging development partners can 'opt out'. The African perspective on the Busan agreement is reflected in the 'African consensus and position on aid effectiveness' document (African Union 2011), which stresses, among other issues, the unfinished aid effectiveness debate and the role of Regional Economic Communities (RECs) in the promotion of South-South cooperation. However, many African 
recipient countries also have a reduced willingness to implement the Busan agreement, which can be directly related to gradual reduction of aid flows compared to other inflows, such as Foreign Direct Investment (FDI), portfolio inflow, remittances and earnings from exports (African Economic Outlook 2013). This low appetite from African recipient countries is unfortunate as annual aid flows to Africa are still about US $\$ 50$ billion and in the past it was evident that some donor practices were counterproductive in promoting development at country level. For example, it is agreed that development assistance that has not been aligned to the national planning framework can be counterproductive to achieving national development goals.

Conflict-sensitive countries received additional attention as part of the 'New Deal for engaging in fragile states'. The New Deal was endorsed by 41 countries and multilateral organisations at the Fourth High Level Forum on Aid Effectiveness in Busan, South Korea, in November 2011. Emerging development partners, such as Brazil, China and Korea, are also members of the New Deal. The New Deal approach aims to improve the effectiveness and efficiency of development assistance in conflictsensitive countries by focusing on inclusive and country-led transitions, building mutual trust between aid-recipient fragile states and donors, and monitoring progress through peace-building and state-building goals. The emphasis of national ownership fits well with the approach of South-South collaboration that emphasises the respect for national sovereignty.

Initially there were seven pilot countries, of which five are in Africa, which proposed to implement the New Deal at country level and subsequently share their experience at global level. ${ }^{2}$ However, the New Deal had its own challenges. Firstly, although the focus of the New Deal was to improve the working methods in post-conflict countries, some fragile states expected that participation in this initiative would lead to additional financial resources. However, this was not forthcoming, partially due to financial constraints of donor countries. Secondly, the label of 'fragile' for a country has a negative stigma and does not help attract FDI, tourism and other private investment activities - all critical for a successful transition from post-conflict reconstruction to sustainable development.

\section{Challenges of post-conflict countries and South-South cooperation}

The post-conflict reconstruction and peacebuilding challenges are extensive and discuss issues such as roving and stationary bandits (Olson 2000), greed versus grievance (Collier and Hoeffler 2001), natural resources and extractive industries (Rigterink 2010), and horizontal and vertical inequality (Collier and Hoeffler 2004). The interrelationship between institutions, weak states, social contract, human development and political instability is equally important in peace-building. The 2011 World Development Report was dedicated to the theme of 'Conflict, Security and Development' and emphasised that breaking the cycle of violence not only requires security, justice and employment, but also legitimate institutions and governance structure (World Bank 2011).

In many sub-Saharan fragile states, both China and traditional donors play an important role in the reconstruction and peace-building process. This includes building physical infrastructure, basic social services, stable public finances, sufficient economic growth and employment creation. Post-conflict reconstruction has a higher success rate in establishing stable democracies and peace processes when it is accompanied by economic growth in the aftermath of conflict (Travers and Owen 2007). However, the key challenge to success for the development community is to adapt to the dynamic process of peace-building, which is only driven by local actors (Brinkerhoff 2011). This is why the principles of the 'New Deal' include national ownership and fits well with the South-South approach that respects the principles of national sovereignty.

A key element in peace-building is restoring economic growth, and requires the rebuilding of physical infrastructure, education and health services and diversification of economic activities that have often reduced to the point of subsistence. This means that after a period of civil war, there is tension between the lack of fiscal revenues and expenditures necessary to stabilise and strengthen the peace-building process, in particular the clearance of civil servants' salary arrears, and to integrate various armed factions into one unified army. The 'buying' of the peace is often challenging, as many African fragile states are under a tight IMF macroeconomic surveillance programme. 
These IMF programmes are a precondition by other multilateral and bilateral donors to provide further aid such as budget support and debt relief.

It is within this context that private sector driven investments from China in post-conflict countries have demonstrated a higher 'risk appetite' compared to companies from traditional donors (Schiere, Ndikumana and Walkenhorst 2011). This is not only the case for large-scale investment in the extractive industry, but also for small and medium-sized enterprises (SMEs). In particular, Chinese SMEs are becoming visible in retail, the service industries and small-scale manufacturing in Africa. Contrary to public perception, the main motivations for Chinese SME investments in Africa are not the financial incentives provided by the 'going global' policy of the Chinese government, but rather market-driven incentives, such as access to local markets in Africa and strong competition in the domestic Chinese market that forces these companies to move to other countries (Gu and Schiere 2011).

These private sector investments with a higher 'risk appetite' can lead to increases in public revenue and economic growth in fragile states. In turn, this reduces the risk of relapsing back into conflict and weakens the negative relationship between weak economic growth and lack of political stability. This is referred to as Collier's 'conflict trap' (Collier 1999). Even if sustainable peace is achieved, there is still a long-term risk of countries sliding back into conflict. More precisely, it is estimated that 90 per cent of civil wars occur in countries that have already suffered from conflict in the last 30 years (World Bank 2011).

\section{Case studies of four African fragile states}

As the major emerging development partner, China is changing the donor landscape in fragile countries in Africa, although the impact is different depending on the context. Four fragile states are therefore analysed, which are respectively, Liberia, Angola, Mali and Sudan. These countries have been chosen as they represent the diversity of post-conflict countries in Africa. More specifically, Angola and Sudan are endowed with massive natural resources and 'Beijing consensus' is evident, while Liberia and Mali maintain strong relationships with traditional donors. The country case studies also reflect the different stages of reconstruction after civil strife, with Angola and Liberia enjoying more than a decade of peace, while Mali is consolidating its peace process and North and South Sudan still need to find a lasting solution to border disputes and the sharing of oil revenue. Finally, some of these case studies also reflect the growing willingness of China to participate in UN peacekeeping operations, but only if there is a clear African mandate, as expressed by the African Union and other Regional Economic Communities.

\section{Case study 1: Liberia - complementarity between North-South and South-South cooperation}

The case of Liberia clearly demonstrates the complementarity between various development cooperation models. Liberia's relationship with traditional donors has been strong due to two factors. Firstly, Liberia has historical and cultural ties with the United States, which takes the lead among donors in mobilising the international community for financial and UN peacekeeping contributions. Secondly, there is a clear 'brand value' benefit with President Sirleaf, who was the first female head of state in Africa and Nobel laureate, and who, overall, has promoted good governance and emphasised poverty reduction policies. These two factors make it easier to defend development assistance to Liberia in parliaments of traditional donor countries. The 'brand value' has directly benefited Liberia, including by providing a speedy debt relief under the Heavily Indebted Poor Countries (HIPG) process of US $\$ 3.17$ billion.

In Liberia, companies from China, India and Malaysia have invested in the extractive industries and large-scale agricultural production. In this regard, there seems to be a different perception of risk and opportunities by companies from emerging developing countries compared to enterprises from traditional donor countries. These investments in the extractive sector not only have a direct positive impact on economic growth, but will in the near future generate significant royalty payments. The first observation is that in the medium term, public revenues generated by investments in extractive industries will be complementary to budget support. The second observation is that international multinational and Chinese companies have similar social and environmental safeguard modalities, and both finance Community Development Funds which channel 
financial resources to regions that have negative ramifications caused by mining activities.

Finally, it should be emphasised that China, as the dominant emerging development partner in Liberia, is flexible and has demonstrated that it can adapt to the domestic political environment in different African countries. China's development cooperation is estimated at US\$20 million annually and mainly finances the building of health clinics, university campuses and renovation of ministries. Although China implements its development projects bilaterally, there is coordination with traditional donors at project and strategic levels. This is through the Economic Management team, the highest body that reviews development projects in Liberia, which is managed by the Ministry of Planning and Economic Affairs. The effective coordination between traditional donors and China can be attributed to the fact that there are no strategic interests or competition in Liberia which is in contrast to some other resource-rich African countries.

\section{Case study 2: Angola - South-South cooperation 'infrastructure-for-oil' loans}

Unlike Liberia, Angola is endowed with massive oil and natural resource wealth and China has taken the lead in financing post-conflict reconstruction efforts. Indeed, the 'Angola model' (Corkin 2011) is often referred to as an 'infrastructure-for-oil' relationship as Angola is using oil revenues to finance the reconstruction of the country, including key public investment projects in infrastructure, telecommunications, and agro-businesses. These investments are financed through a mixture of instruments such as lines of credit and loans which were guaranteed by oil exports. These sources of financing are tied and tender contracts are allocated to Chinese companies.

The Angolan case study is a clear example of a 'Beijing consensus', which focuses on private sector development while at the same time respecting national sovereignty, although there has recently been some re-engagement with traditional development partners, as is evident from the approval of the IMF standby arrangement (IMF 2012). However, there are two observations in relation to the 'Angola model'. Firstly, there are some concerns on the sustainability of some investment projects, taking into account Angola's challenging human and institutional capacity (Alves 2012). Second, tied aid and lack of international competition can lead to poor quality infrastructure, although it should be emphasised that it is the Angolan government's responsibility to supervise investment projects and ensure quality control.

Finally, in terms of evolving South-South cooperation, it should be noted that Angola is becoming a provider of development assistance. Bilaterally this country has been providing support to Guinea-Bissau, a small Lusophone country and fragile state in West Africa. More recently, Angola contributed to ADF-13 (African Development Bank 2013), which provides concessional financing for low-income African countries. As ADF is a centrally managed fund, South-South development contribution reduces fragmentation of development assistance.

\section{Case study 3: Mali-China's engagement beyond economic issues}

Mali has a strong relationship with traditional donors and until recently was considered a stable democracy. This relationship was anchored with France due to the extensive network of investment, trade and development cooperation. In addition, France has a large migrant community originally from Mali, which ensures that there are clear electoral and political reasons to maintain a close relationship between the two countries. Although Mali has an historical relationship with Ghina dating back to independence, the current Mali-China relationship is driven by economic factors. A quarter of Mali's export is destined for China. However, from a Chinese economic perspective, Mali is of modest importance and this country does not have large investments or strategic assets, although there is a growing class of Chinese entrepreneurs in the hotel, restaurant and services industry sectors (Cissé 2012).

Mali is an example of how China is becoming more involved in Africa beyond economic issues. Although France supported the re-establishing sovereignty in northern Mali in January 2013, both China and the Economic Community of West Africa States (ECOWAS) contributed to the United Nations Multidimensional Integrated Stabilization Mission in Mali (MINUSMA). Indeed, China is contributing several hundred UN peacekeepers, which for the first time in its 
history include the deployment of combat troops, although China prefers to use the term security force (Hille 2013). Despite not having any significant strategic investment in the country, China is supporting regional stability, which is aligned with its expanding global interests. The participation of regional organisations was key to ensuring that there was regional support to maintain Mali's sovereign integrity (Shinn 2013).

Although Mali's state capacity is weak, there are clear complementarities between traditional development partners and China. Traditional development partners could work on supporting political process and governance (Sun and Rettig 2013), while China supports development through bilateral channels by building infrastructure and sending agricultural experts and medical teams. Chinese development assistance in infrastructure is critical as socioeconomic development challenges in Mali and this country is ranked 182 out of 186 on the Human Development Index. These socioeconomic development challenges, combined with North-South inequality in Mali, are one of the underlying reasons for instability and conflict in the country.

\section{Case study 4: Sudan - limitations of non-interference and supporting mediation}

China currently imports 60 per cent of Sudan's oil output (Carmody and Taylor 2010) and has invested over US $\$ 12.5$ billion in the oil industry in both North and South Sudan. Much of these investments are in the disputed regions of South Kordofan and Abyei oilfield, while pipelines and ports are in the north. These oil investments were built when Sudan was still a unified country. After the partition, North and South Sudan failed to agree on the exact border and did not agree on tariffs or fees for use of North Sudan's pipelines. This has led to the shutdown of oil production and royalty payments that created a serious fiscal crisis in both North and South Sudan. Prior to the oil shutdown, oil revenues, totalling about US $\$ 400$ million per month, had represented 82 per cent of South Sudan's gross domestic product and 98 per cent of government revenues (Dewaal 2013; Lagerkvist 2012).

North and South Sudan have built up different donor relations. For North Sudan, which has a strong relationship with China, the 'Beijing consensus' is evident. In South Sudan, which became independent in July 2011, traditional donors are more active in supporting reconstructions and humanitarian aid. China also provides development aid and low-interest credit. However, the continuous dispute between the two countries makes it difficult to address issues such as arrears and debt relief - a critical area for traditional donors and multilateral development banks. This has been further complicated by the recent fighting between various factions in South Sudan.

China's investments in North and South Sudan lead to it having a direct interest in stability. Indeed, this country case study indicates the limitations of a policy of caution in terms of not interfering in domestic affairs. It is for this reason that China has been actively supporting mediation efforts led by the African Union and United Nations (Africa Research Institute 2012). China also supports stability by providing non-combat troops to the African Union/United Nations Hybrid Operation in Darfur (UNAMID). Besides the safeguarding of Chinese investments, China is also influenced by mandates of regional African organisations which are aligned with its principles of respecting national sovereignty and noninterference in the domestic affairs of a country.

\section{Results of analysis}

China is changing the donor landscape at global level and in fragile states. The discussion of global South-South cooperation trends and the four case studies provides interesting insights into how China is changing the donor landscape in African fragile states by presenting the diversity of conflict-sensitive countries on the continent. These case studies also indicate that China is one of the driving forces of South-South collaboration and that it is pursuing a 'win-win' approach based on respecting national sovereignty and non-interference principles. The following issues can be emphasised:

1 China development cooperation modalities and aid instruments are different compared to traditional DAC donors. Ensuring positive development outcomes requires strong national leadership by the recipient country and a coherent development plan. This is also the challenge for fragile states that lack the capacity to coordinate donors. The additional development opportunity from emerging development companies are driven by the 
private sector activities that are characterised by a higher 'risk appetite' for investments in the extractive industries. This can promote growth and generate much needed public revenues, necessary to 'buy' the peace and fund the rebuilding of infrastructure and public services, which is clearly evident in Angola. The challenge is that these investments are capital intensive and can lead to enclave development, lack of broad-based growth and rent-seeking behaviour, which in turn could have a negative impact on development and increase the risk of recurring violence (Collier 2006).

2 African fragile states with limited natural resources are more dependent on traditional donors, in particular in the immediate aftermath of post-conflict reconstruction efforts. In these countries traditional development partners often use aid instruments such as budget support and debt relief. This provides some 'fiscal space' to 'buy' the peace. In resource endowed fragile states, China has demonstrated that it is willing to support reconstruction efforts by building an infrastructure based on future revenues from the extractive industries. As is demonstrated by the case of Angola, this can dramatically speed up reconstruction efforts, although there are still enormous socioeconomic development challenges. These resource-rich countries appreciate China's approach of respecting national sovereignty and non-interference in the domestic affairs of the recipient country.

3 China is flexible in its approach and adapts to the national institutional environment, which is in line with the non-interference of domestic affairs principles. For example, in Liberia, China has applied the same socioeconomic safeguards as other multinational companies, and contributions to the Community Development Fund ensure that the local population around the extractive sites benefits from these investments.

4 China is also expanding its activities in supporting UN peacekeeping operations in Africa by contribution to the missions in Mali and Sudan. Indeed, in some cases, such as in Mali, China is motivated by contributing to regional stability as it does not have large-scale investments in this country. However, China will only support these interventions if there is a clear regional mandate provided by the African Union, or a Regional Economic Community, so that the principles of protecting the sovereignty of the country are respected.

5 There is a tendency that South-South cooperation will not necessarily follow the DAC model and lead to a synthesis of development assistance (Walz and Ramachandran 2011; Paulo and Reisen 2010). This is the reason why emerging development partners emphasise the voluntary nature of some of the commitments to aid effectiveness in the Busan agreement. While these new development cooperation models provide additional opportunities for the financing of post-conflict reconstruction efforts, it equally important for fragile states to ensure that these different modalities are aligned to a national development plan. This can be challenging as many African conflict-sensitive countries do not necessarily have the capacity to coordinate development assistance.

It is evident from the above-mentioned issues that China is changing the development landscape in Africa. However, it is equally important to highlight that as part of broader South-South cooperation there is also a clear increase of development support between African countries. A clear example is the financial contribution of Angola, Libya and South Africa to the African Development Fund (ADF), which provides concessional financing to low-income African countries (African Development Bank 2013). This regional dimension, or intra-African development, is part of a growing trend in Africa that recognises that regional development frameworks are a prerequisite for long-term growth on the continent. This regional dimension is becoming more important in promoting China-Africa trade as well. For example, in 2011 the East African Community signed an agreement with the Chinese government to foster economic, trade, investment and technical cooperation (Africa Research Institute 2012).

\section{Conclusion}

It is evident that China is changing the development landscape in African fragile states by providing additional development and financing opportunities. However, this will also lead to more fragmented aid modalities as China does not follow DAC development modalities. To 
ensure that these additional development financing opportunities are harnessed would require the capacity to align all development partners to the national development plan. This is a challenge for many fragile states that, at least in the early phase of post-conflict recovery, lack the capacity of coordinator donors. Two policy options can be considered. Firstly, all development partners could support fragile states by improving transparency of their interventions, thereby facilitating the coordination of development cooperation. Secondly, fragile states can designate a lead development partner to support coordination activities in the country, although once capacity is sufficient, this should be undertaken by the aid-recipient government itself. These approaches will support the successful transition from fragility to sustainable development.

\section{Notes}

* Richard Schiere is Chief Results Officer in the Quality Assurance and Results Department of the African Development Bank Group. The findings, interpretations and conclusions expressed in this article are entirely those of the author and do not necessarily represent the view of the African Development Bank, its Board of Directors, or the countries they represent.

1 Although there are many definitions of fragility, this article uses the African Development Bank definition, which defines

\section{References}

African Development Bank (2013) Participants

Reaffirmed their Commitment to Africa at ADF 13th

Replenishment, 27 September 2013, www.afdb.org (accessed October 2013)

African Economic Outlook (2013) African Economic Outlook 2013: Structural Transformation and Natural Resources, Tunis: African Development Bank and Organisation for Economic Co-operation and Development (OECD)

African Economic Outlook (2012) African Economic Outlook 2012: Promoting Youth Employment, Tunis: African Development Bank and Organisation for Economic Co-operation and Development (OECD)

African Economic Outlook (2011) African Economic Outlook 2011: Africa and its Emerging Partners, Tunis: African Development Bank and Organisation for Economic Co-operation and Development (OECD)
Another observation is that China has a growing stake in regional stability as its investments increase in Africa. Although China's policy is still guided by respecting national sovereignty and non-interference in the domestic affairs of other countries, it is also starting to contribute to UN peacekeeping operations as a means to promote stability. One key condition for China's participation, however, is a clear mandate by African regional bodies such as the African Union and REGs. With this approach China can support stability on the continent, while at the same time maintaining its principles of respecting national sovereignty and non-interference in the domestic affairs of other countries.

fragile states as a harmonised average CPIA rating of the African Development Bank and World Bank of 3.2 or less - or a UN or regional (AU, European Union) peacekeeping or peace-building mission during the preceding three years. See Harmonized List of Fragile Situations FY13 (World Bank 2013).

2 The pilot countries that are participating in the 'New Deal for engaging in fragile states' are respectively: Afghanistan, the Central African Republic, Democratic Republic of Congo, Liberia, Sierra Leone, Somalia and Timor-Leste.

Africa Research Institute (2012) 'Between Extremes: China and Africa', Africa Research Institute Briefing Note 1202, London: Africa Research Institute

African Union (2011) Final Draft African Consensus and Position on Development Effectiveness, www.un.org/ en/ecosoc/newfunct/pdf/ luxembourg_afr_pos_busan.pdf (accessed October 2013)

Alden, C. (2013) 'China and the Long March into African Agriculture', Cahiers Agricultures 22.1: $16-21$

Ashoff, G. (2010) 'Triangular Cooperation: Opportunities, Risks, and Conditions for Effectiveness', Development Outreach 12.2: 22-4

Bräutigam, D. (2010) 'China, Africa and the International Aid Architecture', African Development Bank Group Working Papers Series 107, Tunis: African Development Bank 
Bräutigam, D. (2009) The Dragon's Gift: The Real Story of China in Africa, Oxford: Oxford University Press

Brinkerhoff, D. (2011) 'State Fragility and Governance: Conflict Mitigation and Subnational Perspectives', Development Policy Review 29.2: 131-53

Buckley, L. (2013) 'Chinese Agriculture Development Cooperation in Africa: Narratives and Politics', IDS Bulletin 44.4: 42-52

Busan Agreement (2011) 4th High Level Forum on Aid Effectiveness (2011) Busan Partnership for Effective Development Co-operation Outcome Statement, www.oecd.org/dac/effectiveness/49732200.pdf (accessed October 2013)

Cabral, L.; Shankland, A.; Favareto, A. and Costa Vaz, A. (2013) 'Brazil-Africa Agricultural Cooperation Encounters: Drivers, Narratives and Imaginaries of Africa and Development', IDS Bulletin 44.4: 53-68

Carmody, P. and Taylor, I. (2010) 'Flexigemony and Force in China's Geoeconomic Strategy in Africa: Sudan and Zambia Compared', Geopolitics 15.3: 496-515

Chichava, S.; Duran, J.; Cabral, L.; Shankland, A.; Buckley, L.; Lixia, T. and Yue, Z. (2013) 'Brazil and China in Mozambican Agriculture: Emerging Insights from the Field', IDS Bulletin 44.4: 101-15

Cissé, D. (2012) The Malian Crisis - China's Reaction Capacity at a Test Again?, CCS Commentary, 5 April 2012, Centre for Chinese Studies, www.ccs.org.za (accessed October 2013)

Collier, P. (2006) 'Is Aid Oil?: An Analysis of Whether Africa Can Absorb More Aid', World Development 34.9: 1482-97

Collier, P. (1999) 'On the Economic Consequences of Civil War', Oxford Economic Papers 51.1: 168-83

Collier, P. and Hoeffler, A. (2004) 'Conflicts and Arms Proliferation', in B. Lomborg (ed.), Global Crises, Global Solutions, Cambridge: Cambridge University Press

Collier, P. and Hoeffler, A. (2001) Greed and Grievance in Givil War, World Bank Policy Research Working Paper 2355, Washington DC: World Bank

Corkin, L. (2011) 'Uneasy Allies: China's Evolving Relations with Angola', Journal of Contemporary African Studies 29.2: 169-80

Dewaal, A. (2013) Sizzling South Sudan: Why Oil is not the Whole Story, World Peace Foundation, http://sites.tufts.edu/ (accessed October 2013)

Gu, J. and Schiere, R. (2011) Post Crisis Prospects for China-Africa Relations, African Development
Bank Working Paper Series 124, Tunis: African Development Bank

Hille, K. (2013) 'China Commits Combat Troops to Mali', 27 June, Financial Times, www.ft.com/ $\mathrm{cms} / \mathrm{s} / 0 / \mathrm{e} 46 f 3$ e42-defe-1 le2-881f-00144feab7 de.html\#ixzz2i18FptBY (accessed October 2013)

IMF (2012) Executive Board Completes Sixth and Final Review Under Stand-By Arrangement with Angola and Approves Final US\$132.9 Million Disbursement, International Monetary Fund Press Release 12/109, www.imf.org/external/ np/sec/pr/2012/pr 12109.htm (accessed October 2013)

Kragelund, P. (2008) 'The Return of Non-DAC Donors to Africa: New Prospects for African Development?', Development Policy Review 26.5: 555-84

Lagerkvist, J. (2012) 'China's New Flexibility on Foreign Intervention', Yale Global Online, http://yaleglobal.yale.edu (accessed October 2013)

Langendorf, J. and Mueller, U. (2011) Triangular Cooperation: A Promising New Mode for the Achievement of Aid Effectiveness, Working Paper presented at the 2011 DSA/EADI Conference: Rethinking Development in Age of Scarcity and Uncertainty, New Values, Voices and Alliances for Increased Resilience, York, 19-22 September 2011

Mukwereza, L. (2013) 'Reviving Zimbabwe's Agriculture: The Role of China and Brazil', IDS Bulletin 44.4: 116-26

Olson, M. (2000) Power and Prosperity: Outgrowing Communist and Capitalist Dictatorships, New York: Basic Books

Paulo, S. and Reisen, H. (2010) 'Eastern Donors and Western Soft Law: Towards a DAC Donor Peer Review of China and India?', Development Policy Review 28.5: 535-52

Pierri, F.M. (2013) 'How Brazil's Agrarian Dynamics Shape Development Cooperation in Africa', IDS Bulletin 44.4: 69-79

Rigterink, A. (2010) 'Natural Resources and Civil Conflict: An Overview of Controversies, Consensus and Channels', Economics of Peace and Security Journal 5.2: 17-22

Schiere, R. (2010) 'Building Complementarities in Africa between Different Development Cooperation Modalities of Traditional Development Partners and China', African Development Review 22, Supplementary Issue S1: 615-28

Schiere, R.; Ndikumana, L. and Walkenhorst, P. (2011) China and Africa: An Emerging Partnership 
for Development?, Tunis: African Development Bank Group

Scoones, I.; Cabral, L. and Tugendhat, H. (2013)

'New Development Encounters: China and Brazil in African Agriculture', IDS Bulletin 44.4: $1-19$

Shinn, D. (2013) 'China's Response to the Islamist Threat in Mali', China US Focus, blog, www.chinausfocus.com/peace-security/chinasresponse-to-the-islamist-threat-in-mali/ (accessed October 2013)

Sun, Y. and Rettig, M. (2013) 'Mali After the Election: Priorities of China and the U.S.' BrookingsUp Front, blog, www.brookings.edu/ blogs/up-front/

Travers, P. and Owen, T. (2007) Peacebuilding While Peacemaking: The Merits of a 3D Approach in Afghanistan, UBC SDF Working Paper 3, Kingston: Genter for International Relations Security and Defense

Walz, J. and Ramachandran, V. (2011) Brave New World: A Literature Review of Emerging Donors and the Changing Nature of Foreign Assistance, Center of Global Development Working Paper 273, Washington DC: Center of Global Development Working, www.cgdev.org (accessed 29 March 2014)

World Bank (2013) Harmonized List of Fragile Situations FY13, http://siteresources.world bank.org/EXTLICUS/Resources/5117771269623894864/FCSHarmonizedListFY13.pdf (accessed October 2013)

World Bank (2011) World Development Report: Conflict, Security and Development, Washington DC: World Bank Group

Woods, N. (2008) 'Whose Aid? Whose Influence? China, Emerging Donors and the Silent Revolution in Development Assistance', International Affairs 84.6: 1205-21

Zimmermann, F. and Kimberly, S. (2011) 'More Actors, More Money, More Ideas for International Development Co-operation', Journal of International Development 23.5: 722-38 